\title{
Short-term PV power forecasting based on sky-conditions using intelligent modelling techniques
}

\author{
G. Perveen ${ }^{1 *}$, M. Rizwan ${ }^{2}$, N. Goel ${ }^{3}$ \\ ${ }^{1 *}$ Department of Electronics \& Communication Engineering, Delhi Technological University, Delhi-110042, INDIA \\ ${ }^{2}$ Department of Electrical Engineering, Delhi Technological University, Delhi-110042, INDIA \\ ${ }^{3}$ Department of Electronics \& Communication Engineering, IGDTUW, Delhi-110006, INDIA \\ "Corresponding Author: e-mail: gulegulnar@gmail.com,Tel +91-9891788761
}

\begin{abstract}
The work in this paper involves intelligent modelling techniques i.e. fuzzy logic, Artificial Neural Network (ANN) and Adaptive Neural Fuzzy Inference System (ANFIS) methodologies for estimating the power in a solar photovoltaic (SPV) system. Since, the generation of power is subjective to environmental factors such as ambient temperature, variation in skyconditions and solar insolation, therefore, an intelligent modelling techniques have been proposed for forecasting the power of a solar photovoltaic system employing $210 \mathrm{~W}$ Heterojunction with Intrinsic Thin layer (HIT) photovoltaic modules for different sky-conditions such as clear sky, hazy sky, partially foggy/cloudy sky and fully foggy/cloudy sky conditions respectively for composite climate zone and performance has been evaluated using statistical indicators.
\end{abstract}

Keywords: ANFIS (adaptive neural-fuzzy inference system); ANN (artificial neural network); forecasting; fuzzy logic; skycondition; SPV system.

DOI: http://dx.doi.org/10.4314/ijest.v11i4.5

\section{Introduction}

Last few years have seen tremendous growth in the field of renewable power generation especially in the field of solar energy which employs PV system comprising a number of solar cells (Chauhan and Saini, 2004; Singh, 2003; Zhou et al., 2010). Its advantage is that it generates no greenhouse gas emissions and simple scalability in terms of power needs while the disadvantage is that the output power diminishes due to dust, clouds and other obstructions in the atmosphere (Liu et al., 2015; Jimenez-Perez and Mora-Lopez, 2016). Therefore, an intelligent modelling technique has been introduced to accurately estimate the power generation in SPV system based on sky-conditions.

Detailed literature analysis reveals that the intelligent model available in the literature have been defined for clear skycondition, however, very few models are available in the literature that discussed about variation in sky condition. The objective of the present research is to do the comparative analysis of Fuzzy logic, ANN and ANFIS models in forecasting short-term PV power of SPV systems employing HIT PV modules for different sky conditions i.e. sunny sky, hazy sky, partially foggy/cloudy sky and fully foggy/cloudy sky conditions and for composite climate zone. The performance has been evaluated based on statistical indicators.

The work has been arranged as follows. The data and methodology are presented in Section 2. Section 3 discusses the performance characterization of SPV system. Section 4 is developed to statistical error tests. Results and discussions are presented in Section 5. Conclusion followed by references is presented in Section 6. 


\section{Data and Methodology}

2.1 Meteorological data: In this work, the parameters namely solar irradiance and cell temperature have been achieved from the collaboration of Indian Meteorological Department and National Institute of Solar Energy for composite climate zone (Ajit, 2009; Bansal and Minke, 1988). Further, the normalization of the parameters in 0.1-0.9 range has been done to avoid convergence issues.

2.2 Intelligent modelling for estimating the power of SPV system: Intelligent modelling methods namely fuzzy logic, ANN and ANFIS have been employed to forecast the power in a solar photovoltaic system (Perveen et al., 2019). The details of methodologies are discussed section-wise as follows:

2.2.1 Fuzzy logic: The first section discusses the fuzzy logic modelling where the membership functions are defined in 0.1-0.9 range and a set of rules are explained in the fuzzy logic toolbox of MATLAB. The model has been developed using MamdaniSugeno in fuzzy inference system to forecast the power of SPV system for input parameters namely solar cell temperature and solar insolation while the PV power is the output and presented in Fig. 1 (Chen et al., 2013; Rizwan et al., 2014; Perveen et al., 2018).

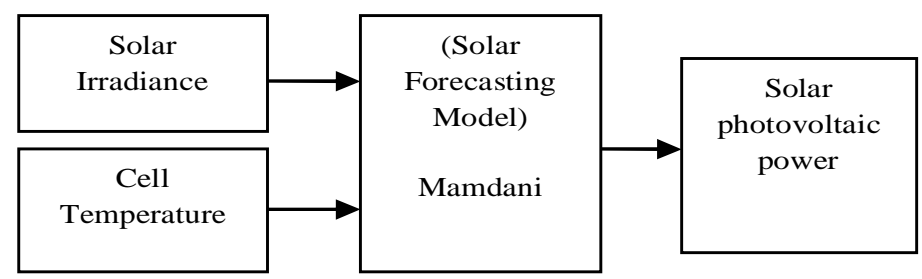

Figure 1. Fuzzy logic based model for estimating power in a solar photovoltaic system.

2.2.2 Artificial Neural Network (ANN): The second section presents an artificial intelligent modelling techniques i.e. Artificial Neural Network (ANN) employing a feed-forward neural network. Model-based on ANN are planned and designed in such manner that output is simulated from the input variables for power forecasting in the SPV system and are presented in Fig. 2 (Azadeh et al., 2013; Azimi et al., 2016; Al-Waeli et al., 2019; Notton et al., 2019).

$$
\text { Input Layer Hidden Layer Output Layer }
$$

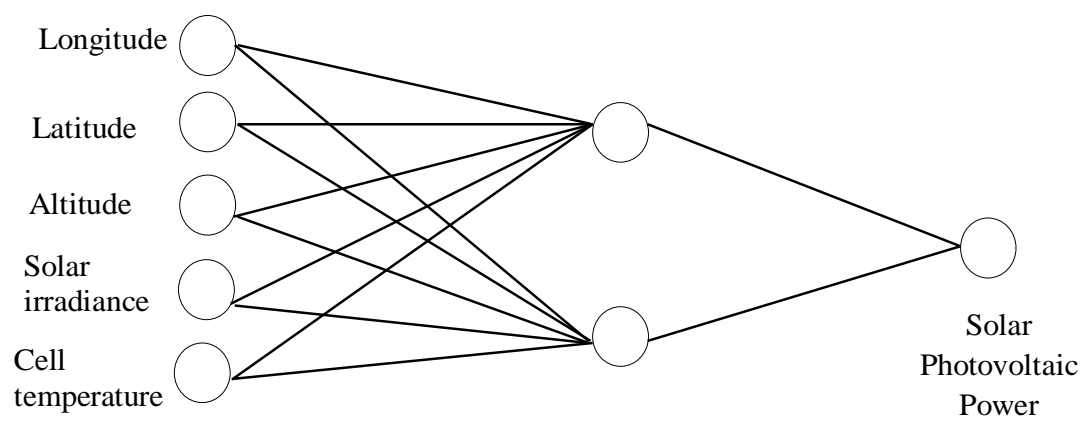

Figure 2. ANN architecture for estimating power in the SPV system.

2.2.3 Adaptive Neural Fuzzy Inference System (ANFIS): The third section presents the combination of ANN and fuzzy logic modelling. ANFIS applies the graphical analysis of Fuzzy-Sugeno system lying within the framework of adaptive networks and relates back-propagation and least squares method using MATLAB software for training and testing the data. The main advantage of using ANFIS methodology is that the convergence rate is much faster (Abu-rub et al., 2013; Jang and Sun, 1995).

\section{Performance Characterization of SPV System}

In the present work, $210 \mathrm{~W}$ HIT solar PV module is chosen and operated at Maximum Power Point (MPP) conditions. Influenced by parameters namely solar irradiance and cell temperature and based on the standard test condition, the power generation can be defined by Eq. (1-2) as shown below (Riffonneau et al., 2011): 


$$
\begin{aligned}
& \mathrm{O}_{\mathrm{PV}}=\left[O_{P V S T C} * \frac{G_{\tau}}{1000} *\left[1-\gamma *\left(T_{j}-25\right)\right]\right] * N_{P V s} * N_{P V p} \\
& \text { and } T_{j}=T_{m}+\frac{G_{T}}{800} *\left(N_{O C T}-20\right)
\end{aligned}
$$

where $\mathrm{O}_{\mathrm{PV}}$,STC is the photovoltaic system rated power output at standard test conditions, $\mathrm{O}_{\mathrm{PV}}$ is the power output of photovoltaic array at MPP, $\mathrm{G}_{\mathrm{T}}$ is solar irradiance in $\mathrm{W} / \mathrm{m}^{2}$ at standard test condition, $\mathrm{N}_{\mathrm{PVS}}$ is the photovoltaic arrays in series in number, $\gamma$ is a temperature parameter at maximum power point, $\mathrm{N}_{\mathrm{PVP}}$ is photovoltaic arrays in parallel in number in ${ }^{\circ} \mathrm{C}$, $\mathrm{T}_{j}$ is the junction temperature of solar panel in ${ }^{\circ} \mathrm{C}$. Given the efficiency of the module is $16.7 \%, \mathrm{~T}_{m}$ is ambient operating temperature range between $-4^{\circ} \mathrm{F}$ to $115^{\circ} \mathrm{F}$ and $\mathrm{N}_{\mathrm{OCT}}$ (Normal operating cell temperature) is $114.8^{\circ} \mathrm{F}$.

\section{Statistical Error Tests}

For evaluating the performance of the models, statistical error tests namely MAPE, NMAE and nRMSE respectively have been used for analysis (Dolara et al., 2018).

4.1 Mean absolute percentage error (MAPE):

$$
\operatorname{MAPE}_{\%}=\frac{1}{n} \sum_{i=1}^{n}\left|\frac{E}{m_{i}}\right| * 100
$$

4.2 Normalized mean absolute error (NMAE):

$$
\mathrm{NMAE}_{\%}=\frac{1}{n} \sum_{i=1}^{n}\left|\frac{E}{\max \left(m_{i}\right)}\right| * 100
$$

4.3 Normalized root mean square error (nRMSE):

$$
\mathrm{nRMSE}_{\%}=\frac{\sqrt{\frac{2}{n} \sum_{i=1}^{n}|E|^{2}}}{\max \left(m_{i}\right)} * 100
$$

where $n$ is the number of observed data, $m_{i}$ and $e_{i}$ are the $i_{t h}$ measured and estimated data respectively, and $\mathrm{E}=\left(m_{i}-e_{i}\right)$ is the absolute error. This definition of error is normalized over the maximum hourly measured data.

\section{Results and Discussions}

Intelligent models have been developed for SPV system which employs $210 \mathrm{~W}$ HIT solar PV module operated at Maximum Power Point Tracking (MPPT) conditions. The data at the input layer comprises cell temperature, solar irradiance and the output layer is the PV power. Fuzzy logic, artificial neural network and ANFIS methodologies have been employed in forecasting power of SPV systems for composite climate zone and are presented in Table 1.

It has been observed from Table 1 that the average mean absolute percentage error by using fuzzy logic methodology is $0.10 \%$; with ANN methodology the mean absolute percentage error reduced to 0.04\%; and with ANFIS methodology the mean absolute percentage error further reduced to $0.01 \%$ which reveals that the obtained results are precise and accurate. This is due to the reason that it employs both fuzzy logic approach and artificial neural network. Further, the graphical representation between the measured and forecasted power employing different methodologies has been presented in Fig. 3.

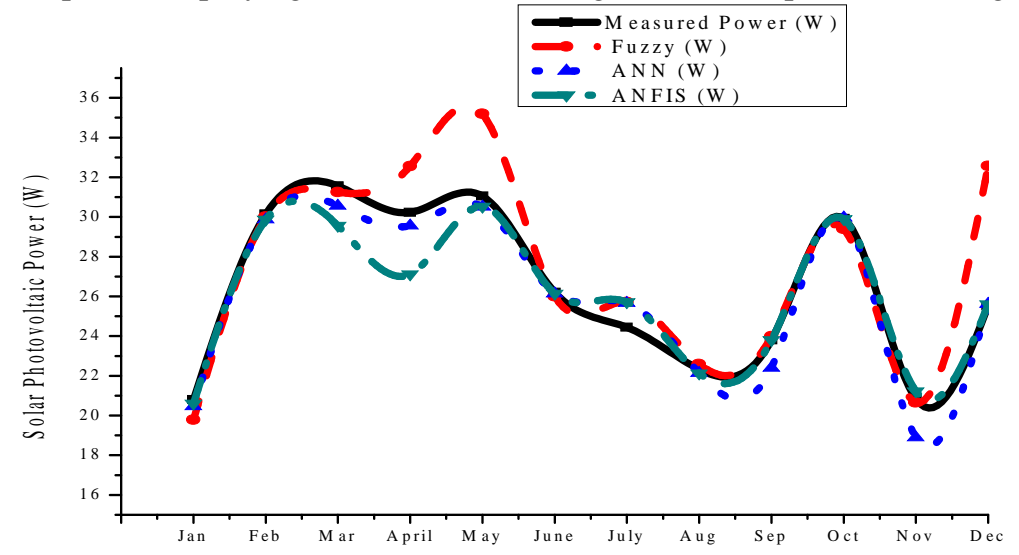

Figure 3. Graphical analysis of measured and forecasted PV power employing fuzzy logic, ANN and ANFIS methodologies. 
Table 1. Intelligent methodologies for forecasting power in a solar PV system employing HIT solar PV modules under composite climate zone

\begin{tabular}{|c|c|c|c|c|c|c|c|c|c|c|c|c|c|c|c|c|c|}
\hline \multirow[b]{2}{*}{ Month } & \multirow[b]{2}{*}{$\begin{array}{c}\text { Solar } \\
\text { Irradiance } \\
\left(\mathbf{W} / \mathbf{m}^{2}\right)\end{array}$} & \multirow[b]{2}{*}{$\begin{array}{l}\mathbf{V}_{\text {oc }} \\
(\mathrm{V})\end{array}$} & \multirow[b]{2}{*}{$\begin{array}{l}\mathbf{I}_{\mathrm{sc}} \\
(\mathrm{A})\end{array}$} & \multirow[b]{2}{*}{$\begin{array}{c}\text { Cell } \\
\text { Temp } \\
\left({ }^{\circ} \mathrm{C}\right)\end{array}$} & \multirow[b]{2}{*}{$\begin{array}{c}\text { Measured } \\
\text { Power } \\
\text { (W) }\end{array}$} & \multicolumn{4}{|c|}{ Fuzzy } & \multicolumn{4}{|c|}{ ANN } & \multicolumn{4}{|c|}{ ANFIS } \\
\hline & & & & & & $\begin{array}{c}\text { Forecasted } \\
\text { Power } \\
\text { (W) }\end{array}$ & $\begin{array}{c}\text { MAPE } \\
(\%)\end{array}$ & $\begin{array}{l}\text { NMAE } \\
(\%)\end{array}$ & $\begin{array}{c}\text { nRMSE } \\
(\%)\end{array}$ & $\begin{array}{c}\text { Forecasted } \\
\text { Power } \\
\text { (W) }\end{array}$ & $\begin{array}{c}\text { MAPE } \\
(\%)\end{array}$ & $\begin{array}{c}\text { NMAE } \\
(\%)\end{array}$ & $\begin{array}{c}\text { nRMSE } \\
(\%)\end{array}$ & $\begin{array}{c}\text { Forecasted } \\
\text { Power } \\
\text { (W) }\end{array}$ & $\begin{array}{c}\text { MAPE } \\
(\%)\end{array}$ & $\begin{array}{c}\text { NMAE } \\
(\%)\end{array}$ & $\begin{array}{c}\text { nRMSE } \\
(\%)\end{array}$ \\
\hline Jan & 361.15 & 81.47 & 0.42 & 28.14 & 20.80 & 19.79 & 0.18 & 0.09 & 0.11 & 20.46 & 0.01 & 0.01 & 0.02 & 20.61 & 0.00 & 0.00 & 0.00 \\
\hline Feb & 461.52 & 82.03 & 0.61 & 35.69 & 30.15 & 30.02 & 0.07 & 0.05 & 0.07 & 29.87 & 0.00 & 0.00 & 0.01 & 29.87 & 0.00 & 0.00 & 0.00 \\
\hline Mar & 548.24 & 83.64 & 0.62 & 40.12 & 31.56 & 31.25 & 0.01 & 0.03 & 0.03 & 30.56 & 0.01 & 0.02 & 0.00 & 29.56 & 0.00 & 0.00 & 0.00 \\
\hline April & 575.12 & 79.62 & 0.60 & 42.53 & 30.23 & 32.56 & 0.15 & 0.06 & 0.04 & 29.56 & 0.00 & 0.02 & 0.00 & 27.12 & 0.00 & 0.00 & 0.00 \\
\hline May & 559.67 & 77.35 & 0.59 & 46.22 & 31.05 & 35.19 & 0.12 & 0.05 & 0.06 & 30.52 & 0.00 & 0.00 & 0.00 & 30.53 & 0.00 & 0.00 & 0.00 \\
\hline June & 537.17 & 76.92 & 0.55 & 45.24 & 26.20 & 26.00 & 0.07 & 0.06 & 0.07 & 26.14 & 0.00 & 0.00 & 0.00 & 26.14 & 0.01 & 0.00 & 0.01 \\
\hline July & 537.81 & 76.66 & 0.05 & 48.28 & 24.45 & 25.72 & 0.05 & 0.04 & 0.05 & 25.67 & 0.02 & 0.02 & 0.03 & 25.71 & 0.00 & 0.00 & 0.00 \\
\hline Aug & 428.80 & 76.90 & 0.47 & 53.27 & 22.33 & 22.59 & 0.06 & 0.04 & 0.05 & 22.14 & 0.03 & 0.01 & 0.04 & 22.13 & 0.00 & 0.00 & 0.00 \\
\hline Sep & 437.51 & 77.78 & 0.50 & 51.62 & 23.80 & 23.99 & 0.13 & 0.07 & 0.09 & 22.40 & 0.27 & 0.12 & 0.19 & 23.80 & 0.07 & 0.03 & 0.04 \\
\hline Oct & 466.57 & 78.74 & 0.63 & 53.21 & 29.92 & 29.40 & 0.07 & 0.06 & 0.07 & 29.97 & 0.01 & 0.00 & 0.01 & 29.90 & 0.00 & 0.00 & 0.00 \\
\hline Nov & 369.82 & 78.48 & 0.44 & 45.08 & 20.85 & 20.65 & 0.13 & 0.05 & 0.06 & 18.90 & 0.03 & 0.01 & 0.02 & 21.23 & 0.00 & 0.00 & 0.00 \\
\hline Dec & 370.84 & 80.66 & 0.47 & 43.36 & 25.53 & 32.57 & 0.12 & 0.01 & 0.09 & 25.62 & 0.10 & 0.08 & 0.43 & 25.61 & 0.00 & 0.00 & 0.01 \\
\hline Avg. & 471.19 & 79.19 & 0.50 & 44.40 & 26.41 & 27.48 & 0.10 & 0.05 & 0.07 & 25.98 & 0.04 & 0.03 & 0.06 & 26.02 & 0.01 & 0.00 & 0.01 \\
\hline
\end{tabular}


From Figure 3, it has been revealed that the forecasted power employing ANFIS methodology closely follows the measured power as compared to others methods such as fuzzy logic and artificial neural network. Further, the power generation in SPV system is greatly influenced by external environmental factors namely sky-conditions, ambient temperature and solar insolation. Therefore, sunny, hazy, partially foggy/cloudy and fully foggy/cloudy sky conditions are considered and performance has been evaluated based on statistical error tests and are presented in Table 2.

Table 2. Short-term PV power forecasting employing HIT solar PV module under composite climate zone

\begin{tabular}{|c|c|c|c|c|c|c|c|c|c|c|}
\hline \multirow[b]{2}{*}{$\begin{array}{l}\text { Sky - } \\
\text { conditions }\end{array}$} & \multirow[b]{2}{*}{$\begin{array}{l}\text { Time } \\
\text { (hr) }\end{array}$} & \multirow[b]{2}{*}{$\begin{array}{c}\text { Cell } \\
\text { Temp. } \\
\left({ }^{\circ} \mathrm{C}\right)\end{array}$} & \multirow[b]{2}{*}{$\begin{array}{c}\text { Solar } \\
\text { Irradiance } \\
\left(\mathbf{W} / \mathbf{m}^{2}\right)\end{array}$} & \multirow[b]{2}{*}{$\begin{array}{l}\text { Measured } \\
\text { Power } \\
\text { (W) }\end{array}$} & \multicolumn{2}{|c|}{ Fuzzy } & \multicolumn{2}{|c|}{ ANN } & \multicolumn{2}{|c|}{ ANFIS } \\
\hline & & & & & $\begin{array}{c}\text { Forecas } \\
\text { ted } \\
\text { Power } \\
(W) \\
\end{array}$ & $\begin{array}{c}\text { MAPE } \\
(\%)\end{array}$ & $\begin{array}{c}\text { Forecas } \\
\text { ted } \\
\text { Power } \\
(W) \\
\end{array}$ & $\begin{array}{c}\text { MAPE } \\
(\%)\end{array}$ & $\begin{array}{c}\text { Foreca } \\
\text { sted } \\
\text { Power } \\
(W) \\
\end{array}$ & $\begin{array}{c}\text { MAPE } \\
(\%)\end{array}$ \\
\hline \multirow{12}{*}{ Sunny sky } & $7: 00$ & 34.11 & 140.93 & 7.00 & 7.02 & 0.0900 & 7.02 & 0.0027 & 7.03 & 0.0036 \\
\hline & $8: 00$ & 40.55 & 273.76 & 13.83 & 15.00 & 0.0840 & 13.84 & 0.0015 & 12.85 & 0.0001 \\
\hline & $9: 00$ & 48.14 & 486.12 & 28.00 & 30.34 & 0.0830 & 28.02 & 0.0009 & 28.01 & 0.0004 \\
\hline & $10: 00$ & 52.23 & 625.25 & 39.83 & 41.66 & 0.0460 & 39.82 & 0.0002 & 39.83 & 0.0002 \\
\hline & $11: 00$ & 57.79 & 783.13 & 52.33 & 54.17 & 0.0350 & 52.31 & 0.0005 & 52.34 & 0.0002 \\
\hline & $12: 00$ & 62.86 & 875.34 & 59.33 & 60.50 & 0.0200 & 59.35 & 0.0003 & 59.06 & 0.0040 \\
\hline & 13:00 & 64.69 & 888.95 & 62.00 & 61.17 & 0.0900 & 61.88 & 0.0018 & 61.99 & 0.0005 \\
\hline & $14: 00$ & 63.91 & 744.96 & 43.17 & 42.00 & 0.0270 & 43.16 & 0.0000 & 43.46 & 0.0052 \\
\hline & $15: 00$ & 61.55 & 726.73 & 48.33 & 46.32 & 0.0420 & 48.32 & 0.0001 & 48.33 & 0.0007 \\
\hline & 16:00 & 58.04 & 549.15 & 34.33 & 31.51 & 0.0820 & 34.34 & 0.0004 & 34.35 & 0.0006 \\
\hline & $17: 00$ & 52.72 & 361.6 & 20.83 & 19.32 & 0.0720 & 20.79 & 0.0024 & 20.82 & 0.0004 \\
\hline & Avg. & 54.24 & 586.90 & 37.18 & 37.18 & 0.0610 & 37.17 & 0.0014 & 37.10 & 0.0010 \\
\hline \multirow{8}{*}{ Hazy sky } & $10: 00$ & 40.83 & 123.1 & 8.00 & 7.12 & 0.0100 & 8.39 & 0.0492 & 8.03 & 0.0031 \\
\hline & 11:00 & 44.49 & 146.12 & 8.50 & 9.70 & 0.0020 & 9.45 & 0.1408 & 8.49 & 0.0011 \\
\hline & $12: 00$ & 43.56 & 307.56 & 19.67 & 24.20 & 0.2300 & 20.25 & 0.0123 & 19.66 & 0.0004 \\
\hline & 13:00 & 52.55 & 519.54 & 45.00 & 45.46 & 0.0100 & 44.82 & 0.0031 & 44.98 & 0.0003 \\
\hline & $14: 00$ & 42.4 & 467.65 & 39.00 & 37.40 & 0.0410 & 39.25 & 0.0060 & 39.01 & 0.0001 \\
\hline & $15: 00$ & 49.36 & 313.06 & 24.50 & 21.50 & 0.0170 & 24.54 & 0.0012 & 24.51 & 0.0004 \\
\hline & $16: 00$ & 41.05 & 185.35 & 11.00 & 10.09 & 0.0830 & 11.68 & 0.0828 & 11.00 & 0.0001 \\
\hline & Avg. & 44.89 & 294.63 & 22.24 & 22.21 & 0.0561 & 22.63 & 0.0422 & 22.24 & 0.0008 \\
\hline \multirow{13}{*}{$\begin{array}{l}\text { Partially } \\
\text { foggy/ } \\
\text { cloudy sky }\end{array}$} & $8: 00$ & 45.79 & 134.08 & 9.67 & 10.26 & 0.0610 & 9.72 & 0.0045 & 9.66 & 0.0008 \\
\hline & 9:00 & 47.49 & 179.69 & 27.33 & 12.99 & 0.5250 & 27.32 & 0.0038 & 12.36 & 0.0670 \\
\hline & $10: 00$ & 52.07 & 355.98 & 32.50 & 30.14 & 0.0730 & 33.33 & 0.0125 & 27.53 & 0.0031 \\
\hline & $11: 00$ & 55.57 & 463.45 & 44.00 & 40.78 & 0.0730 & 44.01 & 0.0010 & 32.56 & 0.0108 \\
\hline & $12: 00$ & 58.38 & 547.32 & 39.50 & 44.39 & 0.1240 & 39.24 & 0.0013 & 43.92 & 0.0005 \\
\hline & 13:00 & 59.96 & 519.74 & 39.83 & 31.40 & 0.2120 & 39.95 & 0.0130 & 39.49 & 0.0026 \\
\hline & $14: 00$ & 55.52 & 492.69 & 50.17 & 40.93 & 0.1840 & 50.28 & 0.0024 & 39.78 & 0.0009 \\
\hline & $15: 00$ & 61.3 & 647.1 & 37.33 & 51.69 & 0.3850 & 37.60 & 0.0178 & 50.22 & 0.0010 \\
\hline & $16: 00$ & 59.64 & 562.02 & 21.17 & 35.16 & 0.6610 & 21.20 & 0.0114 & 37.59 & 0.0139 \\
\hline & $17: 00$ & 50.88 & 299.99 & 15.33 & 18.22 & 0.1880 & 15.39 & 0.0034 & 20.88 & 0.0096 \\
\hline & 18:00 & 50.73 & 235.3 & 7.33 & 12.65 & 0.7250 & 7.53 & 0.0473 & 15.30 & 0.0076 \\
\hline & 19:00 & 47.99 & 156.43 & 7.33 & 7.23 & 0.0130 & 7.75 & 0.0858 & 8.81 & 0.2480 \\
\hline & Avg. & 53.78 & 382.82 & 27.62 & 27.99 & 0.2687 & 27.78 & $\begin{array}{l}0.0305 \\
\end{array}$ & 28.18 & 0.0170 \\
\hline \multirow{8}{*}{$\begin{array}{l}\text { Fully foggy/ } \\
\text { cloudy sky }\end{array}$} & 9:00 & 19.08 & 170.77 & 12.50 & 10.75 & 0.1400 & 12.60 & 0.0066 & 12.48 & 0.0011 \\
\hline & $10: 00$ & 19.02 & 74.87 & 8.33 & 10.62 & 0.2750 & 8.35 & 0.0030 & 8.40 & 0.0099 \\
\hline & $11: 00$ & 23.29 & 96.49 & 11.17 & 8.72 & 0.2190 & 12.78 & 0.1733 & 10.98 & 0.0442 \\
\hline & $12: 00$ & 18.5 & 41.2 & 7.83 & 8.10 & 0.0340 & 7.82 & 0.0018 & 7.81 & 0.0036 \\
\hline & 13:00 & 18.57 & 140.77 & 10.67 & 10.46 & 0.0200 & 10.66 & 0.0002 & 10.63 & 0.0056 \\
\hline & $14: 00$ & 18.59 & 87.31 & 9.83 & 11.14 & 0.1330 & 10.11 & 0.0243 & 10.01 & 0.0735 \\
\hline & $15: 00$ & 17.86 & 164.25 & 12.00 & 10.83 & 0.0970 & 12.01 & 0.0016 & 12.00 & 0.0004 \\
\hline & Avg. & 19.27 & 110.81 & 10.33 & 10.09 & 0.1311 & 10.62 & $\begin{array}{l}0.0301 \\
\end{array}$ & 10.33 & 0.0198 \\
\hline
\end{tabular}


Following inferences can be drawn from Table 2 shown as:

Sunny/Clear sky: $1^{\text {st }}$ June 2015 is considered as a sunny day based on the annual analysis of solar radiation data and availability of sunshine hours. Further, the graphical representation between measured and forecasted power for sunny sky condition have been shown in Figure 4 from which it has been concluded that the forecasted power employing ANFIS methodology represented by cyan colored dash-dot line on hour basis closely follows the measured power represented by the black solid line, whereas some deviation can be seen in terms of fuzzy logic approach represented by red colored dashed line and ANN approach represented by blue colored dot line. The maximum power output is observed to be $62 \mathrm{~W}$ during the day with average MAPE of $0.0610 \%$ using the fuzzy logic methodology; and the error reduced to $0.0014 \%$ by employing ANN methodology; and with ANFIS methodology the mean absolute percentage error has further reduced and is observed to be $0.0010 \%$ respectively.

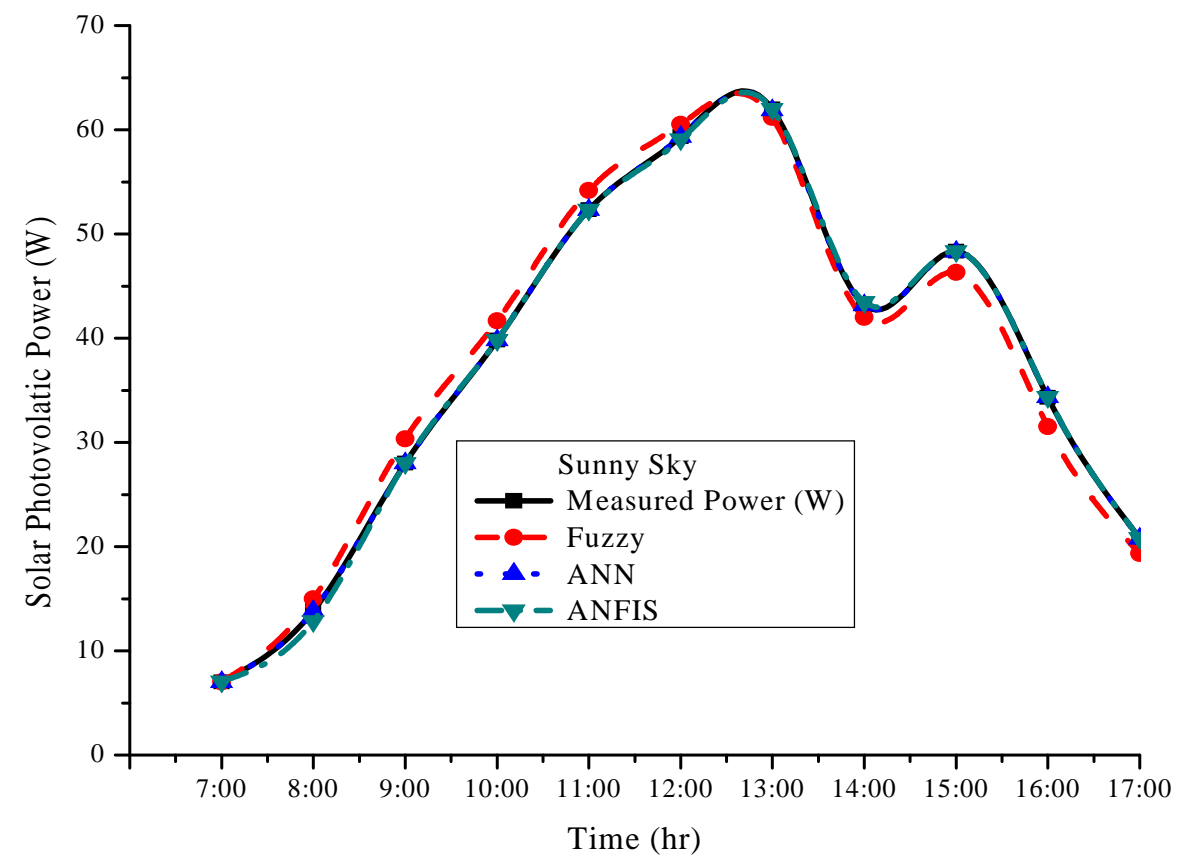

Figure 4. Graphical analysis of measured power and forecasted power employing fuzzy logic, ANN and ANFIS methodologies for sunny sky condition.

Hazy sky: $26^{\text {th }}$ December 2015 is considered as a hazy day based on the annual analysis of solar radiation data and availability of sunshine hours. Further, the graphical representation between measured and forecasted power for hazy sky condition have been shown in Figure 5 from which it has been concluded that the forecasted power employing ANFIS methodology represented by cyan dash-dot line on hour basis closely follows the measured power represented by the black solid line, whereas some deviation can be seen in terms of fuzzy logic approach represented by red dashed line and ANN represented by a blue dot line. The maximum power output is observed to be $50 \mathrm{~W}$ during the day with averaged mean absolute percentage error by employing fuzzy logic methodology is $0.0561 \%$; by employing ANN methodology the mean absolute percentage error is $0.0422 \%$; and by employing ANFIS methodology the error is $0.0008 \%$ respectively.

Partially foggy/cloudy sky: $3^{\text {rd }}$ August 2015 is considered as partially foggy/cloudy day based on the annual analysis of solar radiation data and availability of sunshine hours. Further, the graphical representation between measured and forecasted power for partially foggy/cloudy sky condition have been shown in Figure 6 from which it has been concluded that the forecasted power employing ANFIS methodology represented by cyan dash-dot line on hour basis closely follows the measured power represented by the black solid line, whereas some deviation can be seen in terms of fuzzy logic approach represented by red dashed line and ANN represented by blue dot line. The maximum power output is observed to be $44 \mathrm{~W}$ during the day with averaged mean percentage error by employing fuzzy logic methodology is $0.2687 \%$; by employing ANN methodology the mean absolute percentage error is $0.0305 \%$; and by employing ANFIS methodology the error is $0.0170 \%$.

Fully foggy/cloudy sky: $3^{\text {rd }}$ January 2015 is considered as a fully foggy/cloudy day based on the annual analysis of solar radiation data and availability of sunshine hours. Further, the graphical representation between measured and forecasted power for fully foggy/cloudy sky condition have been shown in Figure 7 from which it has been concluded that the forecasted power employing ANFIS methodology represented by cyan dash-dot line on hour basis closely follows the measured power represented by the black solid line, whereas some deviation can be seen in terms of fuzzy logic approach represented by red 
dashed line and ANN represented by a blue dot line. The maximum power output is observed to be $12 \mathrm{~W}$ during the day with averaged mean absolute percentage error by employing fuzzy logic methodology is $0.1311 \%$; by using ANN methodology the error is $0.0301 \%$; and by employing ANFIS methodology the mean absolute percentage error is $0.0198 \%$ respectively.

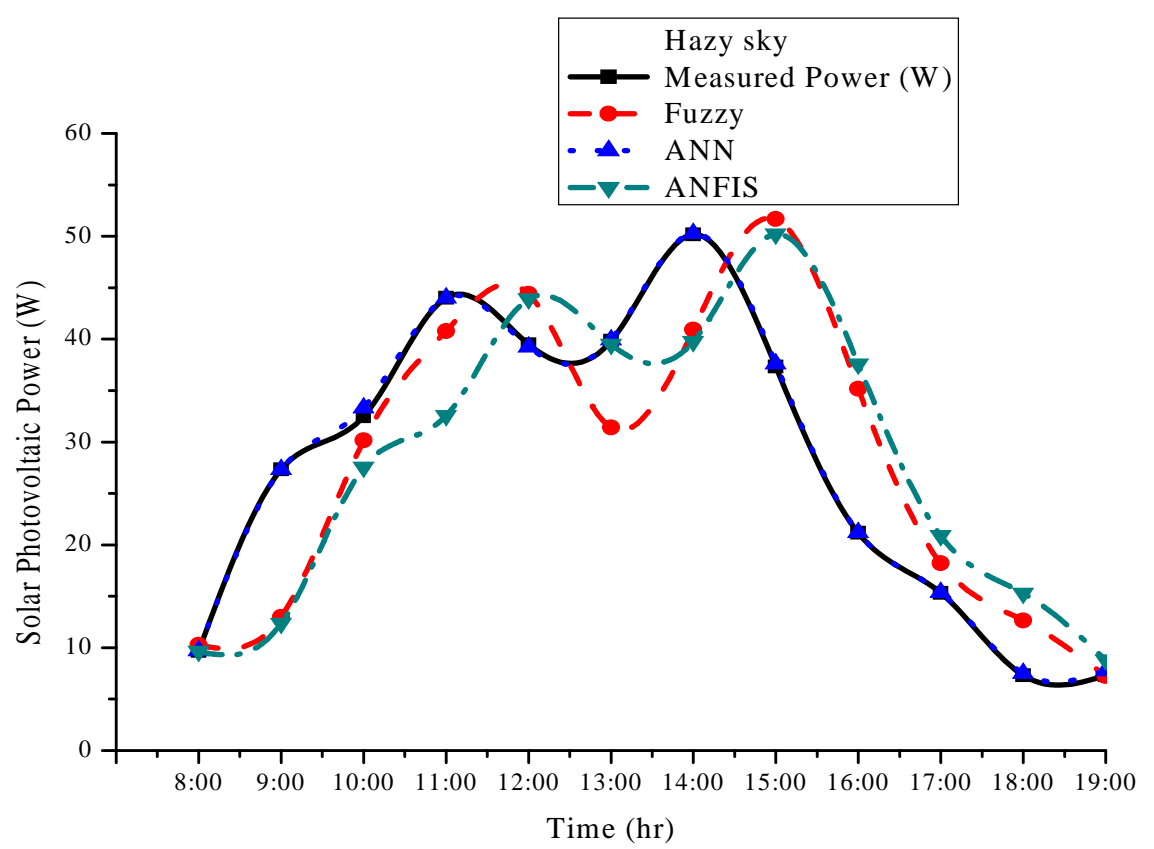

Figure 5. Graphical analysis of measured power and forecasted power employing fuzzy logic, ANN and ANFIS methodologies for hazy sky condition.

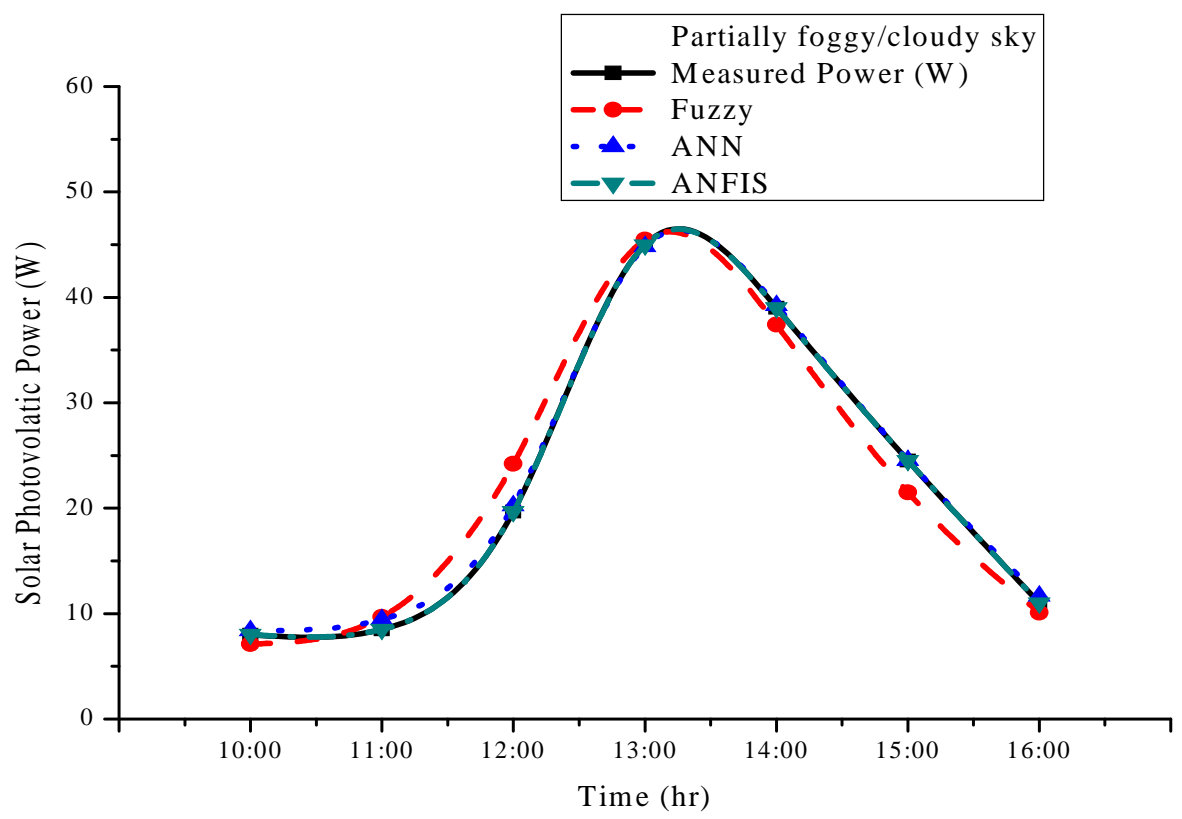

Figure 6. Graphical analysis of measured power and forecasted power employing fuzzy logic, ANN and ANFIS methodologies for partially foggy/cloudy sky condition.

From Table 2, it has been observed that out of the four models, especially the hazy sky model perform well with mean absolute mean percentage error of $0.0008 \%$ in forecasting the power of SPV system followed by sunny sky model with mean absolute percentage error of $0.0010 \%$, partially foggy/cloudy sky model with mean absolute percentage error of $0.0170 \%$, and fully foggy/cloudy sky model with mean absolute percentage error of $0.0198 \%$ respectively by using ANFIS methodology. 


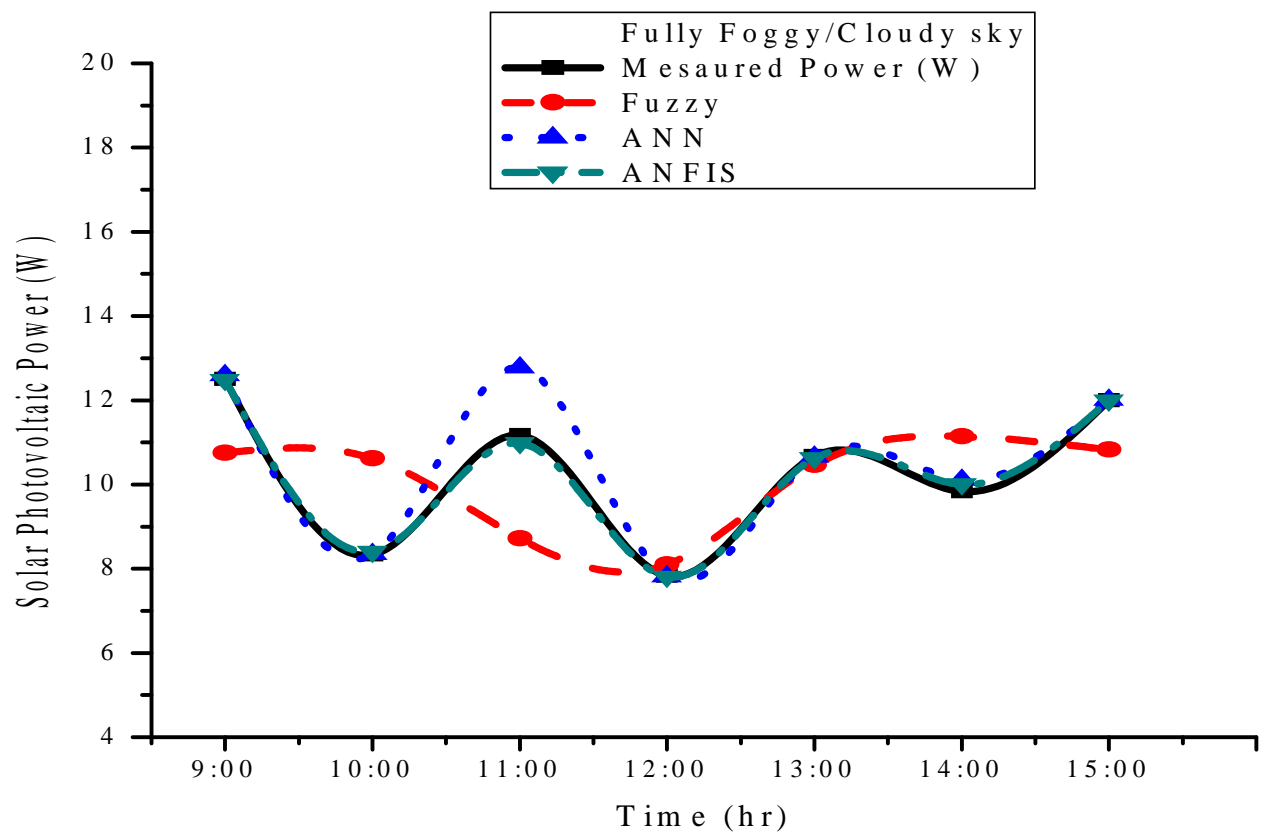

Figure 7. Graphical analysis of measured power and forecasted power employing fuzzy logic, ANN and ANFIS methodologies for fully foggy/cloudy sky condition.

\section{Conclusion}

In the present work, intelligent modelling techniques have been employed for estimating the power of a SPV system for composite climate zone. Simulations have been carried out using fuzzy logic, ANN and ANFIS methodologies for varying sky-conditions i.e. sunny sky, hazy sky, partially foggy/cloudy sky and fully foggy/cloudy sky conditions. Three criteria namely mean absolute percentage error, normalized mean absolute error and normalized root mean square error verifies the forecasting errors of the model. Obtained results reveal the accuracy of the ANFIS model which is far accurate and better than the artificial neural network and fuzzy logic models. ANFIS model has certain advantages such as the ease of design, robustness and adaptability with the non-linearity associated with the data. The ANFIS methodology integrates the features of both fuzzy logic and ANN which increases the system accuracy and makes the system response much faster. The result reveals the model implementation for a broad series of applications. The prediction of solar energy makes it suitable for installation of a monitoring station for a remote place and furthermore, can be extended for sizing of standalone PV system as a part of the future work.

\section{Nomenclature}

$\mathrm{e}_{\mathrm{i}}$

MAPE

$\mathrm{m}_{\mathrm{i}}$

nMAE

nRMSE

$\mathrm{N}_{\text {PVP }}$

$\mathrm{N}_{\text {PVS }}$

$\mathrm{O}_{\mathrm{PV}}$

$\mathrm{O}_{\mathrm{PV}, \mathrm{STC}}$

$\mathrm{T}_{\mathrm{m}}$

$\mathrm{T}_{\mathrm{j}}$

$\mathrm{T}_{\mathrm{o}}$

$\gamma$

\author{
$\mathrm{i}_{\text {th }}$ estimated data (dimensionless) \\ mean absolute percentage error (\%) \\ $\mathrm{i}_{\mathrm{th}}$ measured data (dimensionless) \\ normalized mean absolute error (\%) \\ normalized root mean square error $(\%)$ \\ photovoltaic arrays in parallel (number) \\ photovoltaic arrays in series (number) \\ power output of photovoltaic array at MPP (W) \\ rated power output of photovoltaic array (W) \\ measured ambient temperature $\left({ }^{\circ} \mathrm{C}\right)$ \\ temperature of solar panel $\left({ }^{\circ} \mathrm{C}\right)$ \\ maximum ambient temperature $\left({ }^{\circ} \mathrm{C}\right)$ \\ temperature parameter at MPP
}

\section{References}

Abu-rub H., Iqbal A., Ahmed M., Peng Z., Li Y., and Baoming G. 2013. Quasi-Z-Source Inverter-based Photovoltaic generation system with maximum power tracking control using ANFIS. IEEE Transactions on Sustainable Energy, Vol. 4, No. 1, pp. 11-20.

Ajit, P. T. 2009. Solar radiant energy over India, Ministry of New and Renewable Energy and India Meteorological Department. 
2019, pp. 49-57

Al-Waeli A. H. A., Sopian K., Yousif J. H., Kazem H. A., Boland J., and Chaichan M. T. 2019. Artificial neural network modeling and analysis of photovoltaic/thermal system based on the experimental study, Energy conversion and Management. Vol. 186, pp. 368-379.

Azadeh A., Babazadeh R. and Asadzadeh M. S. 2013. Optimum estimation and forecasting of renewable energy consumption by artificial neural networks. Renewable and Sustainable Energy Reviews, Vol. 27, pp. 605-612.

Azimi R., Ghayekhloo M. and Ghofrani M. 2016. A hybrid method based on a new clustering technique and multilayer perceptron neural network for hourly solar radiation forecasting. Energy Conversion and Management, Vol. 118, pp. 331344.

Bansal N. K. and Minke G. 1988. Climatic zones and rural housing in India. Kernforschungsanlage Julich GmbH, Zentralbibliothek, Julich.

Chauhan A. and Saini R. P. 2014. A review on Integrated Renewable Energy system based power generation for stand-alone applications: Configurations, storage options, sizing methodologies, and control. Renewable and Sustainable Energy Reviews, Vol. 3, pp. 99-120.

Chen S. X., Gooi H. B. and Wang M. Q. 2013. Solar radiation forecast based on fuzzy logic and neural networks. Renewable Energy, Vol. 60, No. (c), pp. 195-201.

Dolara, A., Grimacci, F., Lev, S., Mussett, M. and Ogliari E. 2018. Comparison of training approaches for photovoltaic forecasts by means of machine learning. Applied Sciences, Vol. 8, pp. 1-16.

Jang J. R. and Sun C. 1995. Neuro-fuzzy modelling and control. Proceedings of the IEEE, Vol. 83, No. 3, pp. 378-406.

Jang R. 1993. ANFIS: Adaptive-Network-Based Fuzzy Inference System. IEEE Transactions on Systems, MAN and Cybernetics, Vol. 23, No. 3, pp. 665-685.

Jimenez-Perez P. F. and Mora-Lopez L. 2016. Modeling and forecasting hourly global solar radiation using clustering and classification techniques. Solar Energy, Vol. 135, pp. 682-691.

Liu J., Fang W., Zhang X. and Yang C., 2015. An improved photovoltaic power forecasting model with the assistance of Aerosol Index data. IEEE Transaction on Sustainable Energy, Vol. 6, No. 2, pp. 434-442.

Notton B., Fouilloy A., Duchaud J. L., Voyant C. and Dizene R. 2019. Solar radiation forecasting using artificial neural network and random forest methods: application to normal beam, horizontal diffuse and global components. Renewable Energy. Vol. 132, pp. 871-884.

Perveen G., Rizwan M. and Goel N. 2019. Comparison of intelligent modelling techniques for solar energy forecasting and its application in solar PV systems, IET Energy Systems Integration. Vol. 1, No. 1, pp. 34-51.

Perveen G., Rizwan M. and Goel N. 2018. Intelligent model for solar energy forecasting and its implementation for solar photovoltaic applications. Journal of Renewable and Sustainable Energy. Vol. 10, No. 6, Article ID 063702, pp. 1-23.

Riffonneau Y., Bacha S., Barruel F. and Ploix, S. 2011. Optimal power flow management for grid-connected PV systems with batteries. IEEE Transaction of Sustainable Energy, Vol. 2, No. 3, pp. 309-320.

Rizwan M., Jamil M., Kirmani S. and Kothari D. P. 2014. Fuzzy logic based modelling and estimation of global solar radiation using meteorological parameters. Energy, Vol. 70, pp. 685-691.

Singh G. K. 2013. Solar power generation by PV (photovoltaic) technology: A review. Energy, Vol. 53, pp. 1-13.

Zhou W., Lou C., Li Z., Lu L., and Yang H. 2010. Current status of research on the optimum sizing of stand-alone hybrid solar-wind power generation systems. Applied Energy, Vol. 87, No. 2, pp. 380-389.

\section{Bibliographic Notes}

Dr. Gulnar Perveen is presently associated with research and development activities in Defence Research and Development Organization (DRDO), M/o Defence, India. Prior to joining DRDO she has served National Institute of Solar Energy (NISE), M/o New and Renewable Energy, Delhi, India wherein she was involved in R\&D of solar PV system and it applications. She has obtained her Ph.D. from Delhi Technological University, Delhi, India. She has a research, teaching and industrial experience of 9 years wherein she has published more than 15 research papers in reputed journal and conference proceedings.

Dr. M. Rizwan is presently working as an Associate Professor in the Department of Electrical Engineering, Delhi Technological University (DTU), Delhi, India. He has more than 16 years of teaching and research experience wherein he has published more than 95 research papers in reputed journals and conference proceedings. He is the recipient of the Raman Fellowships for Post-Doctoral research for Indian scholars in the USA, DST Start-Up Grants (Young Scientists). His areas of interest include power system engineering, renewable energy systems particularly solar PV and soft computing applications. He is a senior member of IEEE, life member of ISTE, life member of SSI, member in International Association of Engineers (IAENG) and many other reputed societies.

Dr. Nidhi Goel is working as an Associate Professor in the Department of Electronics \& Communication Engineering at Indira Gandhi Delhi Technical University (IGDTUW), Delhi, India. Prior to joining IGDTUW, she was associated with DTU, Delhi, India. She has teaching and research experience of approximately 17 years wherein she has authored 2 book chapters and published over 45 research papers in reputed journals and conferences proceedings. Her area of interest includes Embedded Systems, Biomedical Image Processing, Renewable Energy and Multimedia Security.

Received July 2019

Accepted September 2019

Final acceptance in revised form September 2019 